\title{
Staff Retention in Developing Countries: A Case Study of an NGO in the Health Sector
}

\author{
Rhoda Cynthia Bakuwa \\ "Corresponding Author" \\ University of Malawi, the Malawi Polytechnic, Private Bag 303, Chichiri, Blantyre 3, Malawi \\ E.mail: rcbakuwa@yahoo.co.uk \\ Francis Chasimpha \\ University of Malawi, the Malawi Polytechnic, Private Bag 303, Chichiri, Blantyre 3, Malawi \\ E.mail: fchasimpha@poly.ac.mw \\ Joyce Masamba \\ University of Malawi, the Malawi Polytechnic, Private Bag 303, Chichiri, Blantyre 3, Malawi \\ E.mail: jmasamba@poly.ac.mw
}

Accepted: Feb 16, 2013 Published: March 18, 2013

Doi:10.5296/ijhrs.v3i1.3104 URL: http://dx.doi.org/10.5296/ijhrs.v3i1.3104

\begin{abstract}
Given the importance of human resources as a source of competitive advantage and the fact that staff turnover is inevitable, the retention of skilled staff is vital in any organizational set up. In the health sector, particularly in developing countries, staff retention is regarded as an important human resource management issue. Any critical shortages prevent the delivery of quality healthcare services. Therefore, it is imperative for managers to identify factors that employees' value and which consequently influence their intention to continue working for an organization. It is against this backdrop that this paper attempted to examine the key determinants of staff retention in developing countries based on a case study of an NGO in the health sector in Malawi. Using survey data collected from 299 employees, the results of this study revealed that it was the non financial/intangible rewards and not the financial package that significantly contributed to employees' feelings of satisfaction and their intention to continue working for the case NGO. These results imply that when designing retention strategies, it is not just about money, but rather, it is important to factor in intangible rewards which could provide psychological satisfaction and may indeed have a deeper and longer lasting effect.
\end{abstract}

Keywords: Staff Retention, Financial Rewards, Non Financial/Intangible Rewards, Psychological Satisfaction, Health Sector. 


\section{Introduction}

Human resource is regarded as a valuable resource in any organization. Armstrong and Baron (2002) state that people and their collective skills, abilities, and experience are now regarded as making a significant contribution to organizational success and as constituting a major source of competitive advantage. Similarly, Aydogdu and Asikgil (2011) assert that in view of rapidly changing business environment, it must not be forgotten that the success and competing power of the organization depend on committed, highly motivated, satisfied and innovative human resources. Therefore, as alluded to by Schreuder and Theron (2001), the retention of talented employees by employers is essential.

Undeniably, the retention of staff has become a major challenge in many organizations in the $21^{\text {st }}$ century because of globalization, among other things. According to Samuel (2008), globalization has tremendously enhanced mobility of skilled individuals, thereby accelerating the rate of employee turnover in organizations. Although turnover could provide opportunities for internal promotion and also the injection of new skills by new employees, Armstrong (2009) stress that turnover of key employees can have a disproportionate impact on the business. As argued by Dess and Shaw (2001), turnover incurs significant costs, both in terms of direct costs (e.g. replacement, recruitment and selection, temporary staff, management time) and indirect costs (e.g. reduced morale, pressure on remaining employees, costs of learning, reduced product/service quality, loss of organizational memory and the loss of social capital). Given the high costs of turnover and its destructive tendency, retention of skilled employees has become strategic and critical to sustainable competition and effective service delivery among organizations in the ever changing world of work (Samuel, 2008). Any organization would strive to retain the human resource needed to successfully attain the organization's goals. In this regard, it is imperative for managers as they design their retention strategies to identify retention variables that would influence the decision of valuable employees to have a longer tenure in an organization.

This study focuses on one of the Non Governmental Organizations (NGO) in Malawi which was established more than twenty years ago to provide quality healthcare services. In the health sector, particularly in developing countries, staff retention is one of the critical human resource issues. Many health systems in Africa, including Malawi, face a number of challenges, one of which is the shortage of human resources for health. The reasons underlying the shortage are multiple and include: limited output from training institutions, high attrition rates resulting from migration and diseases and increased workloads because of HIV and Aids (USAID, 2003). Such a critical shortage prevents organizations operating in the health sector from delivering acceptable quality healthcare services. For instance, according to WHO (2006) it has been noted that a key obstacle to achieving the Millennium Development Goals is attributed to the absence of a mix of trained and motivated health professionals, which affects the performance of the health system. In such an environment, the retention of well trained and skilled staff is critical in order to achieve sustained high levels of service delivery. 
It is therefore important for managers in the health sector to comprehend the factors that are likely to lead to the retention of their staff. This will facilitate the development of well targeted interventions that effectively contribute to staff retention. It is against this backdrop that this paper has attempted to examine the key determinants of staff retention in developing countries using a case study of an NGO in the health sector in Malawi. Knowing what produces satisfied staff is a step towards creating work environments in which committed employees can be retained for as long as is mutually profitable to the organization and the employee.

\section{Literature Review}

\subsection{Components of a Reward System}

The premise of this study is the social exchange theory. Based on this theory, the employment relationship can be regarded as an exchange type of relationship. As applied to work organizations, the social exchange theory states that individuals perform for or make contributions to, an organization in exchange for certain rewards or inducements (Mulinge and Mueller, 1998).

The rewards that individuals expect to get in return for their contributions in the workplace can be categorized into 3 broad components :- (1) direct financial rewards - these are direct monetary rewards encompassing the payment of cash to employees for work accomplished or efforts expanded. Examples include salary, wage, incentives, and commissions (Kohli and Deb, 2008); (2) indirect financial rewards - these are indirect monetary rewards and include those items of financial value the organization provides to employees that do not result directly in employee's receiving spendable cash. Examples include medical insurance, life insurance, and various benefits such as company car etc. (3) Non financial rewards - these consist of the satisfaction that a person receives from the job itself or from the psychological and/or physical environment in which the person works (Mondy and Noe, 1996). Examples of this form of reward include opportunities to perform meaningful work, social interactions with others in the workplace, job training, career advancement opportunities, recognition, employer brand, and a host of other similar factors (Kohli and Deb, 2008; Mondy and Noe, 1996).

\subsection{Staff Retention and Job Satisfaction}

Some authors, such as Kohli and Deb (2008) have argued that an organization can use its reward system in order to attract and retain talent needed by the organization. This is probably because rewards seem to greatly impact on employees' level of job satisfaction. Therefore, an organization's reward strategy might be critical in addressing the challenges created by retention.

Although Luthans (2005) affirms that there are other factors that can influence a person to 
leave besides job satisfaction such as the state of the economy and availability of other job opportunities, job satisfaction has frequently been identified as one of the key factors determining someone's intention to leave an organization (Adzei and Atinga, 2012; Aydogdu and Asikgil, 2001; Brough and Frame, 2004; French, 2003; Korunka et. al. 2005; Lumley, et al. 2011; Mobley, 1977; Mulinge and Mueller, 1998; Samuel, 2008). This suggests that employees who are satisfied with their jobs and work environments are more likely to stay with their employers. Even in healthcare institutions, job satisfaction is regarded as an important variable because dissatisfaction can lead to health workers quitting an institution to others that are highly rewarding (Adzei and Atinga, 2012). Therefore, organizations need to take deliberate efforts to assess the levels of employee satisfaction as part of a retention strategy. Indeed, many organizations periodically administer employee satisfaction surveys in order to identify areas of employee satisfaction and dissatisfaction.

Since job satisfaction is a widely researched and complex phenomenon, it follows that there are numerous definitions of the concept (Lumley et. al., 2011). Nonetheless, many authors perceive job satisfaction or dissatisfaction as an attitude that individuals have about their jobs and work environments. For example, Greenberg and Baron (2000) defined job satisfaction or dissatisfaction as a person's positive or negative feelings about their jobs and work environments. Hence, a person with high job satisfaction appears to hold generally positive attitudes, and one who is dissatisfied appears to hold negative attitudes towards their job (Robbins, 1993). For researchers to understand these attitudes, they need to understand the complex and interrelated facets of job satisfaction (Lum et al, 1998; Luthans, 1998; Spector, 1997). A facet of job satisfaction can be described as any part of a job that produces feelings of satisfaction or dissatisfaction (Spector, 1997). Consequently, job satisfaction has several facets such as: management, supervision, co-workers, empowerment, teamwork, the work itself, quality of work life, promotion opportunities, and pay. All these facets can positively or negatively affect an employee's overall satisfaction. This perspective can be useful to organizations that wish to identify employee retention areas in which improvement is possible (Saari \& Judge 2004; Westlund \& Hannon 2008).

\section{Research Questions}

In an attempt to examine key determinants of staff retention in developing countries, this paper investigated the following two questions:

1. Which component(s) of rewards significantly influence satisfaction with the case NGO?

2. What factors significantly influence the intention of staff to continue working for the case NGO?

\section{Methodology}

This paper is based on a broader study that was done in an NGO in the health sector in June 
2011 to determine factors likely to lead to employee job satisfaction and staff retention. At the time of the study, the case NGO had close to 400 members of staff working at various stations located across Malawi. Specifically, data were collected using a structured questionnaire that focused on the perceptions of staff in the case NGO regarding 11 aspects of their jobs, 8 aspects of communication, 3 aspects of pay and benefits, 2 aspects of recognition, 5 aspects of learning and development, 16 aspects related to line management, 6 aspects related to top management, 3 aspects of work-life balance, 6 aspects of fairness and equality, and 8 aspects related to the quality of work life in the case NGO. In total, the respondents were presented with 68 items regarding various aspects of their jobs and their work environment and they were requested to rank each item on a 5 point Likert scale of 1 (strongly disagree) to 5 (strongly agree). Altogether, 383 questionnaires were administered to employees throughout all stations where this case NGO is operating in Malawi except members of the executive management team. The respondents confidentially completed the questionnaires and directly dispatched them in sealed envelopes to the researcher. The results were analyzed using SPSS (Statistical Package for the Social Sciences).

To identify the key factors that significantly influenced satisfaction in the case NGO and the intention of staff to continue working for the case NGO, correlation and regression analysis of survey data was done. Correlation analysis was done to establish the strength and direction of a linear relationship between various pairs of variables of interest. Based on the value of the Pearson product - moment correlation coefficient, only the top ten factors that significantly correlated with employees' satisfaction with the case NGO and the intention of staff to continue working for the case NGO respectively, were selected for regression analysis to determine (1) how well a set of variables was able to predict a particular outcome, and (2) which variable in a set of variables was the major predictor of a particular outcome. All statistical testing was conducted at the significance level of 0.05 .

Independent variables were checked for any evidence of multicollinearity. According to Pallant (2010), multicollinearity exists when the independent variables are highly correlated ( $r=0.9$ and above). The factors in a scale were assessed for reliability and validity. Cronbach Alpha coefficient assesses reliability and to be reliable, a scale should have as high an alpha coefficient as possible of at least 0.7 (Vaus de, 2002:127). A valid Likert Scale should be unidimensional in the sense that it should measure only one concept rather than a mixture of different concepts and corrected item total-correlations provide evidence for the unidimensionality of the scale (ibid:127). To retain in a scale an item should have an item total correlation of at least 0.3 (Pallant, 2010).

\section{Results}

\subsection{Descriptive Statistics of the Study Sample}

299 fully completed questionnaires were received representing a 78\% response rate. In all, there were slightly more male $(n=160 ; 53.5$ per cent $)$ than female respondents $(n=139 ; 46.5$ 
percent). Those performing clinical roles were more $(n=201 ; 67.2$ percent $)$ than those performing non clinical roles $(n=98 ; 32.8$ percent). This is not surprising since this is an NGO offering health related services. In terms of gender composition, there were more females performing the clinical roles $(n=116 ; 83.5 \%)$ than males $(n=85 ; 53 \%)$. With regard to employment status, 99 percent $(n=296)$ of the respondents were full time employees whilst only 1 percent $(n=3)$ were employed on part time basis. Further, the majority of the respondents were employees with no supervisory responsibilities $(n=216 ; 72.2 \%)$, followed by those in supervisory management $(n=47 ; 15.7$ percent) and least were those in middle management positions $(n=36 ; 12$ percent). In terms of length of service, 8.4 percent $(n=25)$ of the respondents had been in service with the case NGO less than 1 year; 18.1 percent $(\mathrm{n}=$ 54) had served the case NGO more than 1 year but less than 3 years, and the majority of the respondents 73.5 percent $(n=220)$ had served the case NGO at least 3 years which provides enough credence of the reliability of the data collected.

\subsection{Factors Contributing to the Highest Level of Dissatisfaction}

Although our overall assessment of the descriptive results showed that respondents expressed some degree of satisfaction with various aspects of their jobs and work environments, they expressed a high level of dissatisfaction with various aspects of their pay and benefits. To assess the perceptions of staff regarding various aspects of their pay and benefits, the respondents were presented with the following three statements: (1) considering my duties and responsibilities, I feel the total package of my pay and benefits is fair; (2) compared to other NGOs, I think my pay and benefits are equitable; and (3) I feel that good performance is acknowledged and rewarded by this NGO. The results are presented in table1.

Table1: Perceptions Regarding Pay and Benefits

\begin{tabular}{|l|l|l|l|l|l|l|}
\hline Factor & $\begin{array}{l}\text { Strongl } \\
\mathbf{y} \\
\text { Disagr } \\
\text { ee/ } \\
\text { Disagr } \\
\text { ee }\end{array}$ & $\begin{array}{l}\text { Neither } \\
\text { Agree } \\
\text { nor } \\
\text { Disagree }\end{array}$ & $\begin{array}{l}\text { Strongl } \\
\text { y Agree } \\
\text { / Agree }\end{array}$ & $\mathbf{N}$ & $\begin{array}{l}\text { Mean } \\
\text { Score }\end{array}$ & $\begin{array}{l}\text { Standard } \\
\text { Deviation }\end{array}$ \\
\hline $\begin{array}{l}\text { Compared to other NGOs, } \\
\text { I think my pay and } \\
\text { benefits are equitable }\end{array}$ & $77.6 \%$ & $10.7 \%$ & $11.7 \%$ & 298 & 2.05 & 1.027 \\
\hline $\begin{array}{l}\text { Considering my duties and } \\
\text { responsibilities, I feel the } \\
\text { total package of my pay } \\
\text { and benefits is fair }\end{array}$ & $71.5 \%$ & $10.4 \%$ & $28.1 \%$ & 298 & 2.20 & 1.104 \\
\hline $\begin{array}{l}\text { I feel good performance is } \\
\text { acknowledged } \\
\text { rewarded by this NGO and }\end{array}$ & $61.3 \%$ & $13.8 \%$ & $24.9 \%$ & 297 & 2.46 & 1.268 \\
\hline
\end{tabular}


The results presented in Table 1 revealed that as many as $78 \%$ of the respondents held the perception that in comparison to other NGOs their pay and benefits were not equitable $(\overline{\mathrm{x}}=$ $2.05 ; \sigma=1.027$ ) and almost $72 \%$ of the respondents felt that the total package of their pay and benefits was not fair considering their duties and responsibilities $(\overline{\mathrm{x}}=2.20 ; \sigma=1.104)$, These results appear to suggest that the majority of the employees in the case NGO held negative feelings regarding various aspects of their pay and benefits in their organization.

\subsection{Satisfaction with the Case NGO}

To rate perceived level of satisfaction, the respondents were requested to indicate their level of disagreement/agreement regarding the statement "overall I am satisfied with the case NGO at the present time" on a scale of 1-5. The results revealed that $68 \%$ of the respondents either strongly agreed/agreed that they were satisfied with the case NGO compared to $17 \%$ who either strongly disagreed/disagreed. The mean score for this variable was 3.77, s.d. $=1.091$, indicating moderate level of satisfaction.

With regard to correlation analysis, the results revealed the existence of significant and positive relationships at the 0.05 level between satisfaction with the case NGO and the perceptions of staff regarding the following top ten factors:

(1) I feel that this NGO is among the best NGOs to work for in Malawi $(r=0.560)$

(2) I feel the future of my career is safe and good in this NGO $(r=0.539)$

(3) Top management have created an open and comfortable work environment $(\mathrm{r}=0.513)$

(4) I believe I have the opportunity for personal development and growth in this NGO $(\mathrm{r}=0.493)$

(5) Top management is committed to good people management $(r=0.465)$

(6) Overall, I have confidence in top management $(\mathrm{r}=0.461)$

(7) Change is managed effectively in this NGO $(r=0.449)$

(8) Communication between departments in this NGO work well $(r=0.440)$

(9) I am satisfied with the opportunities I have to develop my career in this NGO $(r=0.431)$

(10) Top management demonstrate this NGO's core values $(r=0.420)$

A scale comprising these 10 factors was assessed for reliability and validity. The corrected item-total correlation for each one of the 10 factors was greater than 0.3 , hence the scale could be regarded as valid with this study sample. Furthermore, the Cronbach Alpha for the above 10 factors was 0.879 , hence the scale could be considered reliable with this study sample.

Regression analysis was then done to determine (1) how well the above set of 10 factors was able to predict satisfaction with the case NGO and (2) which factor in the above set of 10 factors was the major predictor of satisfaction with the case NGO. Variables whose results were not significant have been excluded. The results of four variables only were statistically significant $(\mathrm{p}<0.05)$ and are presented in Table 2 . These results revealed that the model was 
able to explain $44.6 \%$ of the variance in the perceptions of staff regarding their satisfaction with the case NGO. This implied that satisfaction with the case NGO could significantly be explained by these four factors. However, amongst the four factors, the perception that the case NGO was among the best NGOs to work for in Malawi, had the largest beta coefficient of 0.276 implying that this factor, in comparison with the other factors, made the strongest unique contribution to explaining the perceptions of staff regarding satisfaction with the case NGO.

Table 2: Regression Analysis: Key Predictors of Satisfaction with the Case NGO

\begin{tabular}{|c|c|c|c|c|c|c|}
\hline Factors & & B & std.error & Beta & $T$ & Sig. \\
\hline $\begin{array}{l}\text { I am satisfied } \\
\text { (constant) }\end{array}$ & & 1.257 & .177 & & 7.093 & .000 \\
\hline $\begin{array}{l}\text { The case NGO is } \\
\text { among the Best } \\
\text { NGOs }\end{array}$ & & .254 & .052 & .276 & 4.879 & .000 \\
\hline $\begin{array}{l}\text { I believe I have the } \\
\text { opportunity for } \\
\text { personal } \\
\text { development and } \\
\text { growth in this } \\
\text { NGO }\end{array}$ & & .152 & .042 & .195 & 3.658 & .000 \\
\hline $\begin{array}{l}\text { Top management } \\
\text { have created an } \\
\text { open } \\
\text { comfortable work } \\
\text { environment }\end{array}$ & & .177 & .052 & .191 & 3.402 & .001 \\
\hline $\begin{array}{l}\text { I feel the future of } \\
\text { my career is safe } \\
\text { and good in this } \\
\text { NGO }\end{array}$ & & .162 & .053 & .181 & 3.030 & .003 \\
\hline$R$ Square & $44.6 \%$ & & & & & \\
\hline Adjusted $R$ Square & $43.8 \%$ & & & & & \\
\hline $\begin{array}{l}\text { Regression } F(d f= \\
4,283)\end{array}$ & 57.020 & & & & & \\
\hline$P$ & .000 & & & & & \\
\hline
\end{tabular}

\subsection{Intention of Staff to Continue Working for the Case NGO}

To assess the intention of staff to continue working for the case NGO, the respondents were requested to indicate their level of disagreement/agreement regarding the statement "I intend to continue working for the case NGO in the next 12 months" on a scale of 1-5. The results 
revealed that $88 \%$ of the respondents either strongly agreed/agreed that they intended to continue working for the case NGO compared to only $4 \%$ who either strongly disagreed/disagreed. The mean score for this variable was 4.32 , s.d. $=0.867$, indicating that staff really desired to continue working for the case NGO.

With regard to correlation analysis, the results revealed the existence of significant and positive relationships at the 0.05 level between the intention of staff to continue working for case NGO in the next 12 months and their perceptions regarding the following top 10 factors:

(1) I am proud to work for this NGO $(r=0.672)$

(2) Overall, I am satisfied with this NGO $(r=0.506)$

(3) I feel that this NGO is among the best NGOs to work for in Malawi $(r=0.492)$

(4) Top management are committed to good people management $(r=0.456)$

(5) Top management have created an open and comfortable environment $(r=0.435)$

(6) Overall, I have confidence in top management $(\mathrm{r}=0.417)$

(7) I feel the future of my career is safe and good with this NGO $(r=0.403)$

(8) Change is effectively managed $(r=0.399)$

(9) Top management provide effective leadership $(r=0.386)$

(10) I am satisfied with opportunities I have to develop my career within this NGO $(\mathrm{r}=0.330)$

A scale comprising these 10 factors was assessed for reliability and validity. The corrected item-total correlation for each one of the 10 factors was greater than 0.3 , hence the scale could be regarded as valid with this study sample. Furthermore, the Cronbach Alpha for the above 10 factors was 0.887 , hence the scale could be considered reliable with this study sample.

Regression analysis was then done to determine (1) how well the above set of 10 factors was able to predict the intention of staff to continue working for the case NGO in the next 12 months, and (2) which factor in the above set of 10 factors was the major predictor of the intention of staff to continue working for the case NGO in the next 12 months. Variables whose results were not significant have been excluded. Only the results of three variables were statistically significant $(\mathrm{p}<.05)$ and are presented in Table 3 . These results revealed that the model was able to explain $51.1 \%$ of the variance in the intention of staff to continue working for the case NGO in the next 12 months. This implied that the intention of staff to continue working for the case NGO could significantly be explained by these three factors. However, amongst the three factors, respondents' feelings of being proud to work for the case NGO had the largest beta coefficient of 0.521 implying that this factor, in comparison with the other two factors, made the strongest unique contribution to explaining the intention of staff to continue working for the case NGO in the next 12 months.

In fact, $92 \%$ of the respondents either strongly agreed/agreed that they were proud to work for this case NGO compared to only $2 \%$ who either strongly disagreed/disagreed. The mean score for this variable was 4.37 , s.d. $=0.729$. Further analysis was done to examine why 
respondents felt proud to work for the case NGO. The results of correlation analysis revealed the existence of a stronger positive and significant relationship between respondents' feelings of being proud to work for the case NGO and the perception that the case NGO was among the best NGOs to work for in Malawi $(r=0.524, \mathrm{p}=<0.05)$.

Table 3: Regression Analysis: Key Predictors of the Intention of Staff to Continue Working for the Case NGO

\begin{tabular}{|c|c|c|c|c|c|c|}
\hline Factors & & $B$ & $\begin{array}{l}\text { std. } \\
\text { error }\end{array}$ & Beta & $T$ & Sig. \\
\hline $\begin{array}{l}\text { Intention to continue } \\
\text { working for the case } \\
\text { NGO (constant) }\end{array}$ & & .669 & .220 & & 3.043 & .003 \\
\hline $\begin{array}{l}\text { I am proud to work } \\
\text { for this NGO }\end{array}$ & & .618 & .059 & .521 & 10.491 & .000 \\
\hline $\begin{array}{l}\text { Top management are } \\
\text { committed to good } \\
\text { people management }\end{array}$ & & .141 & .037 & .182 & 3.824 & .000 \\
\hline $\begin{array}{l}\text { Overall, I am satisfied } \\
\text { with this NGO }\end{array}$ & & .122 & .041 & .153 & 2.953 & .003 \\
\hline$R$ Square & $51.1 \%$ & & & & & \\
\hline Adjusted $R$ Square & $50.6 \%$ & & & & & \\
\hline $\begin{array}{l}\text { Regression } F(d f=3, \\
285)\end{array}$ & 99.442 & & & & & \\
\hline$P$ & .000 & & & & & \\
\hline
\end{tabular}

\subsection{Summary of Key Predictors in this Study}

Overall, based on the results of regression analysis, the key factors that led to feelings of satisfaction among staff in this study were: -

(1) The perceptions that the case NGO was among the best NGOs to work for in Malawi ( $\beta=$ $0.276, t=4.879, p=<0.05)$;

(2) The perceptions that staff had the opportunity for personal development and growth in the case NGO $(\beta=0.195, t=3.658, p=<0.05)$;

(3) The perceptions that top management had created an open and comfortable work environment $(\beta=0.191, t=3.402, p=<0.05)$; and

(4) The perceptions that their careers were safe and good in this NGO ( $\beta=0.181, t=3.030, p$ $=<0.05)$.

In addition, the key factors that contributed to the intention of staff to continue working for the case NGO were: -

(1) The employees' sense of pride because they were working for the case NGO ( $\beta=0.521, t$ $=10.491, p=<0.05)$; 
(2) The perception that top management was committed to good people management $(\beta=$ $0.182, t=3.824, p=<0.05$ ); and

(3) Employees' overall satisfaction with the case NGO $(\beta=0.153, t=2.953, p=<0.05)$.

\section{Discussion}

\subsection{Pay and Satisfaction}

The results of this study revealed that the majority of staff felt that their total pay and benefits package was not fair in itself and also when compared to other NGOs. Notwithstanding such perceptions, the majority of staff were still satisfied and expressed their intention to continue working for the case NGO. So, the results showed no correlation between pay package and level of satisfaction as well as the intention of staff to continue working for the case NGO. Similarly, a study by Mulinge and Mueller (1998) found no significant relationship between pay and job satisfaction amongst agricultural technicians in Kenya.

However, the relationship between pay and job satisfaction is not consistent within the available literature. There are some studies (see for example Ali, 2008; Dieleman et al. 2003; Luddy, 2005) that have found significant relationships between pay and job satisfaction. Armstrong (2009) argues that although money may in itself have no intrinsic meaning, it acquires significant motivating power because it comes to symbolize so many intangible goals. Hence, according to Akintoye (2000), financial incentives in the form of money remain, arguably, the most significant strategy of motivation. Even among health workers, some studies have shown that low salaries primarily account for job dissatisfaction and migration of such workers (Dieleman, et al., 2003; Stilwell, et al. 2004). In such circumstances, improving job satisfaction and efforts to retain staff require offering higher financial rewards that would make health workers see alternative employment less attractive. Paying health workers with adequate salaries and allowances on regular basis has been identified as a key driver of motivation and retention (WHO, 2006).

Nevertheless, it is worth noting that employee perspectives about work have been changing. Apart from their pay check, modern employees value quality of working life. Rolando (2000) as cited in Ferreira (2008) posits that a fat salary is down the list of things that the modern employees are looking for. Likewise, in the opinion of Amar (2004), money was until a couple of decades back, the only outcome that employers offered to their employees. But that practice has changed. If managers reward performance with only money, in many ways, they lose the retention war, because there are other more powerful motivators of talent (Hays, 1999). In the context of health care, Mathauer and Imhoff (2006), found that non financial incentives do play an important role when it comes to increasing motivation of health staff. It is therefore not surprising that a number of other researchers such as Adzei and Atinga (2012) contend that financial incentives alone are necessary but may not be sufficient to stimulate health worker retention such that a variety of non financial packages are crucial within the broader pathways of retaining health workers. 
The following paragraphs briefly discuss the key determinants of employee satisfaction and the intention of staff to continue working for the case NGO based on the results of this study.

\subsubsection{Best NGO and Proud to Work for the Case NGO}

In this study, staff were satisfied and expressed their desire to continue working for the case NGO primarily because they felt that the case NGO was among the best NGOs to work for in Malawi and they had a sense of pride working for such an NGO. It therefore seems that by being associated with this NGO, there was a sense of psychological satisfaction amongst staff. This seems to suggest that staff felt that working for this NGO psychologically promised a distinctive kind of employment experience hence they considered this NGO as a great place to work. This is a form of intangible rewards which basically provide intrinsic motivation. According to Armstrong (2009), intrinsic motivators are concerned with the 'quality of work life' - feelings of satisfaction arising from the work itself and the work environment. Such intrinsic motivators are likely to have a deeper and longer term effect because they are inherent in the individuals and their work and not imposed from outside (ibid).

\subsubsection{Opportunity for Personal Development and Growth}

In the $21^{\text {st }}$ century, many organizations are no longer operating in stable environments but in rapidly changing, and uncertain competitive environments. Such environments require organizations to adopt new ways of doing things, be creative, innovative and flexible. Therefore, employees who are continuously advancing their knowledge and skills are more valuable since they enhance the competiveness of an organization. In this study, the perception that staff had opportunities for personal growth and development influenced feelings of satisfaction. Provision of opportunities for personal growth and development demonstrate an organization's commitment towards enhancing employees' knowledge and skills. It is through such activities that people are able to acquire and develop relevant new knowledge, skills, capabilities, behaviors and attitudes that enable them to perform their current jobs satisfactorily or prepare them for enlarged or higher level responsibilities in the future (Armstrong, 2009).

Undeniably, the extent to which health workers are exposed to opportunities for career and continuous professional development, such as sponsorship to attend both short and advanced courses in their areas of specialization, has a strong motivational effect on retention (Adzei and Atinga, 2012). Such opportunities enable health workers to cope better with the requirements of their job, enable them to take up more challenging duties, and also enable them to achieve personal goals of professional advancement (Mathauer and Imhoff, 2006). 
One of the critical roles of management is to create a work environment that will endear the organization to employees (Samuel, 2008). In this study, staff were also satisfied and oriented to pursue retention because they held the perception that top management was committed to good people management and had also created an open and comfortable work environment. Such an environment provides an opportunity for staff to participate in decision making on matters that concern them and their workplace. Research has revealed that health workers feel better motivated when for instance managers give them the opportunity to participate in regular meetings (Hagopian et al., 2009) and allow their voices to be heard.

According to Taplin and Winterton (2007) as cited by Samuel (2008), managers have the responsibility to structure the workplace and provide employees with an environment that enables them resist external attractions such as higher pay in other organizations. Sherman et al. (2006) also found in their research that the majority of employees in the organizations surveyed planned to remain with their organizations at least for the next five years because of the prevailing culture of management care. Similarly, in a Deloitte and Touche survey, Conradie (2008) cited in Ferreira (2008) reports that the single most important factor that elongates employee's stay in an organization is management style - "the quality of the relationship an employee has with his or her immediate manager". This point to the fact that successful strategies to encourage retention partly rest on the ability of health managers to strengthen their relationship with subordinates (Adzei and Atinga, 2012).

\subsubsection{Career Safety}

Another important job satisfaction variable identified in this study was job security. Staff expressed satisfaction with the case NGO and hence their intention to continue working for the case NGO because they felt that their careers were safe and good in the case NGO. According to Samuel (2008), employees place great importance on their jobs because it provides them with a guaranteed source of income with which socio-economic stability and psychological well-being are achieved which are critical issues in developing economies with high incidence of poverty.

\section{Conclusion and Managerial Implications}

For any organization to effectively attain its objectives, staff retention is vital. An assessment of the key factors that led to staff satisfaction and desire to continue working for the case NGO revealed that these factors had nothing to do with the financial aspects of the reward package. Rather, the factors were related to aspects of management, learning and development as well as other aspects of the organization itself. All these key factors fell in the category of the non financial/intangible rewards. These results seem to corroborate the claim by Herzberg's two factor theory that while the lack of money can cause dissatisfaction, its provision does not result in satisfaction, hence the things that make people satisfied on the job 
are different in kind from the things that make them dissatisfied (Hiam, 2003).

It can therefore be concluded that when it comes to staff retention, even in developing countries, it is not just about money. Rather, the satisfaction that a person receives from the job itself or from the psychological and/or physical environment in which a person works can play a very critical role. Thus intangible rewards are salient. According to Armstrong (2009:744) intangible rewards can help deliver a positive psychological contract which can serve as a differentiator in the recruitment market which is much more difficult to replicate than individual pay practices such that the organization can become an 'employer of choice' and 'a great place to work' hence attracting and retaining the talented people it needs.

The results of this study imply that when designing retention strategies management can consider various things that staff would value and which would help to persuade them to remain with the organization. More importantly, managers need to seriously focus on the intangible rewards. They can endeavor to do something about their management style, learning and development opportunities, the quality of working life provided by the organization, the attractiveness of the organization itself, and possibly create an employer brand. Such intangible rewards would create a sense psychological satisfaction amongst staff. Nonetheless, money should also be an important component of any retention strategy. Money may be regarded as a powerful motivating force because it is linked directly or indirectly to the satisfaction of many needs such that it can have an immediate and powerful effect, although not necessarily lasting for long (Armstrong, 2009). Money can therefore provide motivation in the right circumstances but the pay systems have to be designed properly and be perceived as fair and equitable. Definitely, the combined effect of different types of rewards would make a deeper and longer lasting impact on the satisfaction and retention of staff.

\section{Study Limitations}

Firstly, the survey questions focused on the perceptions of employees completing the questionnaire regarding the various aspects of their jobs and work environment. However, this does not diminish the value of the results because how individuals perceive their reality forms the basis upon which their decisions take place (O'Neill, 1998). In addition, since most of the respondents to this study had worked for the case NGO for at least 3 years it would be likely that they had an understanding of the central issues of concern.

Secondly, this study was conducted in Malawi with a random sample specifically drawn from the case NGO. Statistically, this limits the generalizability of the results of this study to the population from which the sample was drawn. However, this does not weaken the significance of the findings of this study which corroborate with the findings of most of the studies in this area and also brings into the limelight the importance of psychological satisfaction in the retention of staff. 


\section{References}

Adzei, F. \& Atinga, R. (2012). Motivation and retention of health workers in Ghana's district hospitals: Addressing the critical issues. Journal of Health Organization and Management, 26 (4), $467-485$.

Akintoye, I.R. (2000). The place of financial management in personnel psychology. University of Ibadan, Ibadan, paper presented at Personnel Psychology Guest Lecture Series.

Ali, N. (2008). Factors affecting overall job satisfaction and turnover intention. Journal of Managerial Sciences, 11 (2), 239- 252.

Amar, A. D. (2004). Motivating knowledge workers to innovate: a model integrating motivation dynamics \& antecedents. European Journal of Innovation Management, 7 (2), 89-101.

Armstrong, M. (2009). Armstrong's handbook of human resource management practice. London: Kogan Page.

Armstrong, M. \& Baron, A. (2002). Strategic HRM: The route to improved business performance. London: CIPD.

Aydogdu, S. \& Asikgil, B. (2011). An empirical study of the relationship among job satisfaction, organizational commitment and turnover intention. International Review of Management and Marketing, 1 (3), 43-53.

Brough, P. \& Frame, P. (2004). Predicting police job satisfaction and turnover intentions: the role of social support and police organizational variables. New Zealand Journal of Psychology, 33 (1), 8-16.

Dess, G.D. \& Shaw, J. D. (2001). Voluntary turnover, social capital, and organizational performance. Academy of Management Review, 26 (3), 446-456.

Dieleman, M., Cuong, P.V., Anh, L.V. \& Martineau, T. (2003). Identifying factors for job motivation of rural health workers in North Vietnam. Human Resources for Health, 1 (10).

French, W.L. (2003). Human resources management. New York: Houghton Mifflin Publishers.

Greenberg, J. \& Baron, R. A. (2000). Behavior in Organizations. New Jersey: Prentice Hall.

Hagopian, A., Zuyderduin, A., Kyobutungi, N. \& Yumkella, F. (2009). Job satisfaction and morale in the Ugandan health workforce. Health Affairs, 28 (5), 863-75. 
Hays, S. (1999). Generation X \& Y and the art of the reward. Workforce, 78 (11), 44-48.

Hiam, A. (2003). Motivational management: inspiring your people for maximum performance. New York: American Management Association.

Kohli, A. \& Deb, T. (2008). Performance Management. New Delhi: Oxford University Press.

Korunka, C., Hoonakker, P.L.T. \& Carayon, P. (2005). A universal turnover model for the IT work force - a replication study. In Carayon, Kleiner, Robertson and Hoonakker (Eds), Human Factors in Organizational Design and Management -VIII, (pp 467-472), Santa Monica, CA: IEA Press.

Luddy, N. (2005). Job satisfaction amongst employees at a public health institution in the Western Cape. Mini-thesis for Magister Commercii in the Department of Industrial Psychology, Faculty of Economic and Management Science, University of the Western Cape

Lum, L., Kervin, J., Clark, K., Reid, F. \& Sirola, W. (1998). Explaining nursing turnover intent: job satisfaction, pay satisfaction or organizational commitment. Journal of Organizational Behavior, 9 (3), 305-21.

Lumley, E.J., Coetzee, M., Tladinyane, R. \& Ferreira, N. (2011). Exploring the job satisfaction and organizational commitment of employees in the information technology environment. Southern African Business Review, 15 (1), 100 - 118.

Luthans, F. (2005). Organizational behavior. New York: McGraw-Hill.

Luthans, F. (1998), Organisational behaviour., Boston: Irwin McGraw-Hill.

Mathauer, I. \& Imhoff, I. (2006). Health worker motivation in Africa: the role of non financial incentives and human resource management tools. Health Resources for Health, 4 (34).

Mobley, W. H. (1977). Intermediate linkages in the relationship between job satisfaction and employee turnover. Journal of Applied Psychology, 62, 237-240.

Mondy, R. \& Noe, R. (1996). Human resource management. New Jersey: Prentice Hall.

Mulinge, M. \& Mueller, C. (1998). Employee job satisfaction in developing countries: the case of Kenya. World Development, 26 (12), 2181-2199.

O’Neill, N. G. (1998). AIDS workplace policy and implementation in local government: an analysis of departmental variation. Miami: Florida International University. 
Pallant, J. (2010). SPSS Survival Manual. Berkshire: Open University Press.

Robbins, S. (1993). Organizational behavior: concepts, controversies, and applications. New Jersey: Prentice Hall.

Saari, L. \& Judge, T. (2004). Employee attitudes and job satisfaction. Human Resource Management, 43 (4), 395-407.

Samuel, M. (2008). Using motivational strategy as panacea for employee retention and turnover in selected public and private sector organizations in the Eastern Cape Province of South Africa. Master of Commerce in Industrial Psychology in the Faculty of Management and Commerce, University of Fort Hare.

Schreuder, A. \& Theron, A. (2001). Careers: an organizational perspective. Cape Town: Juta.

Sherman, D., Alper, W. \& Wolfson, A. (2006). Seven things companies can do to reduce attrition. Journal of the South African Institute of People Management, 24 (3), 8-11.

Spector, P. 1(997). Job satisfaction: application, assessment, causes and consequences. California: Sage.

Stilwell, B., Diallo, K., Zurn, P., Vujicic, M., Adams, O. \& Dal, P.M. (2004). Migration of health-care workers from developing countries: strategic approaches to its management. Bulletin of the World Health Organization, 82, 595-600.

USAID (2003). The health sector human resource crisis in Africa: an issues paper. Washington, DC: United States Agency for International Development, Bureau for Africa, Office of Sustainable Development.

Vaus de, D. (2002). Surveys in social research. London: Routledge.

Westlund, S. \& Hannon, J. (2008). Retaining talent: assessing job satisfaction facets most significantly related to software developer turnover intentions. Journal of Information Technology Management, 19 (4), 1-15.

WHO (2006). The world health report - working together for health. Geneva: WHO. 